\title{
INSTRUCTIONAL LEADERSHIP PRACTICES IN INTERNATIONAL SCHOOLS IN MALAYSIA: A CASE STUDY
}

\author{
Joseph Velarde ${ }^{a *}$ \\ a'Institute of Educational Leadership, University of Malaya, Malaysia \\ *Corresponding Author Email: jmvelarde85@gmail.com
}

\section{ABSTRACT}

The ever-growing popularity of international schools in Malaysia opens a new perspective in the study of instructional leadership in this academic system from the point of view of school leaders. Focusing on instructional leadership models by Hallinger \& Murphy and Robinson, this case study has been conducted in three international schools in Kuala Lumpur, Malaysia as it aims to present existing instructional leadership practices and perspectives of school leaders in this setting. A qualitative interpretive approach was utilized by probing into the common practices of international school leaders in Malaysia. Using purposive and snowball sampling, six school leaders from three international schools from Kuala Lumpur, Malaysia participated in this study through semi-structured interviews. The responses from the leaders were triangulated with observation field notes and document analysis. Coded and thematically analyzed using ATLAS.ti, the responses gathered from the interviews with the school leaders showed clear inclination of international school leadership towards instructional leadership especially when it comes to communicating goals, promoting a positive learning climate, and ensuring an orderly supportive environment. Aside from presenting the reality of school leadership in these international schools, this study seeks to share practices worth emulating and developing not only in academic institutions but also in other multicultural organizations.

Keywords: educational leadership, international schools, instructional leadership 


\section{INTRODUCTION}

Globalization has transformed $21^{\text {st }}$ century education through international schools (Keller, 2015). The continuous movement of people globally leads to the demand for a multi-cultural school system with a flexible range of curricula accepted anywhere in the world (Hayden \& Thompson, 2008; Hill, 2015). Hence, more than tearing down economic boundaries, globalization enables free flow of knowledge acquisition from different perspectives with international schools as a melting pot and training ground (Cambridge \& Thompson, 2004).

As a result of the free movement of people worldwide and the desire to provide education that best suits the needs of foreign students, the international school system keeps itself distinct from national schools and even from other private schools (Bailey, 2015; Hayden \& Thompson, 2008). What makes an international school different from their national school counterpart starts with the influx of expat and local parents seeking for a more flexible international curriculum accepted in any school or university anywhere in the world (Hill, 2015). The autonomy of international schools, detached from the national curriculum and the governmentenforced standardised tests, leads to the growth of international schools (Bates, 2012; Hayden \& Thompson, 2008).

Serving as a host country to more than 120 international schools (Nasa \& Pilay, 2017), Malaysia hosts a "heterogeneous mix of ethnic groups" primarily Malay, Chinese, and Indians, practicing different religious beliefs and cultural practices (Noor \& Leong, 2013, p. 715). Being a multi-racial nation, this country has been continuously attracting people all over the world; thus, the demand for international 
schools in Malaysia has been on the rise in the past years (Bailey, 2015). The number of international schools has increased from 66 in 2010 to 126 with more than 60,000 students in 2017 from 30,000 in 2013 (Nasa \& Pilay, 2017; PEMANDU, 2013).

Recent studies in instructional leadership in Malaysia focus mainly on the function and impact of principals in government schools (Abdullah \& Kassim, 2011; Hallinger, 2011; Musa \& Noor, 2017). In the Malaysian context, school principals indicate awareness of their responsibility as leaders committed to the teaching and learning process (Harris et al., 2017; Sharma, 2012). Although the Malaysian Education Blueprint (Ministry of Education, 2012) recommends developing instructional leaders in government schools, international schools in Malaysia have the autonomy to weigh in on such recommendation.

The demand for international schools, particularly in Malaysia, comes with the quest to improve this system of education (Hayden \& Thompson, 2008; Keung \& Rockinson-Szapkiw, 2013; Lee, Hallinger \& Walker, 2012). However, studies on international schools are still far from the point of saturation (Keung \& RockinsonSzapkiw, 2013). Given that international schools have only gained traction in the latter part of the $20^{\text {th }}$ century, there are still gaps to fill in order to have a clearer picture of this system (Hayden \& Thompson, 2008). Accordingly, exploring instructional leadership practices is one of the many gaps worthy of further investigation in order to improve international schools and meet the demands of $21^{\text {st }}$ century education. 
Henceforth, this study deems the potentials of presenting perspectives from three international schools in Malaysia to contribute to the development of existing literature in instructional leadership and international schools in general.

\section{INTERNATIONAL SCHOOLS}

International schools started on the premise of serving the families of diplomats, army personnel, and entrepreneurs in host countries (Bailey, 2015; Hayden \& Thompson, 2008). Currently, admissions to international schools are not only exclusive to the children of expatriate workers or diplomats, but to anyone who has access, resources, and eligibility to study in such schools (Hayden \& Thompson, 2008). From its conception during the industrial revolution era to modern day globalised society, these schools have made their niche in the field of education distinct from public and private academic institutions (Sylvester, 2002).

Basically, this openness to accept any eligible student no matter where they come from has become the primary selling point of international schools (Hayden \& Thompson, 2008). Its multi-cultural environment that hosts administrators, teachers, and students from different countries clearly sets it apart from public and private schools (Keller, 2015; Mancuso, Roberts \& White, 2010). Due to this naturally diversified setting, an international curriculum "that is distinctly different from the host country curriculum" also needs to be followed in order to cater to the needs of the stakeholders (Keller, 2015, p. 901). International schools have the liberty to select and implement a particular curriculum, although they still operate under the authority of the host country's education ministry (Hayden \& Thompson, 2008; Hill, 2015; Keller, 2015). 
As a host country, Malaysia continuously diversifies its education system by providing opportunities for the growth of international schools (PEMANDU, 2013). The demand for international school education is brought about by the desire to study overseas, and the need to improve English language skills (Lee et al., 2012; Bailey, 2015). The diversity of Malaysia's population, together with the dynamics of international education in a Muslim majority country (Bailey, 2015; Tamatea, 2008), makes this host country an ideal setting for this study.

\section{INSTRUCTIONAL LEADERSHIP}

International schools, as an organisation and a system, operate under the supervision of formal and informal leaders (Bailey, 2015; Mancuso et al., 2010; Keung \& Rockinson-Szapkiw, 2013). In privately-run international schools, a board of directors oversee the general management of the school while academic and cocurricular management are given to school principals or heads of schools (Hayden \& Thompson, 2008). This system is divided into different departments according to the curriculum being implemented, hence the need for other positions like coordinator, subject heads, or team leaders to name a few (Keller, 2015).

Since there is no single definition for leadership (Bush, 2007; Fink, 2005; Lumby \& Coleman, 2007), it is imperative to set certain significant parameters in contextualising the discussion on instructional leadership in international schools. As shown in Table 1, two of the contemporary models in instructional leadership from Hallinger \& Murphy (1985) and Robinson (2007) establish key dimensions to probe international school leadership: 
Table 1: Key dimensions of models in instructional leadership

\begin{tabular}{lll}
\hline \multicolumn{1}{c}{ Hallinger and Murphy (1985) } & \multicolumn{1}{c}{ Robinson (2007) } \\
\hline Dimensions & Defining the school's mission & Establishing goals \& expectations \\
& $\begin{array}{l}\text { Managing the instructional } \\
\text { program }\end{array}$ & Strategic Resourcing \\
& $\begin{array}{l}\text { Planning, Coordinating, and } \\
\text { evaluating teaching and the } \\
\text { Promoting a positive school } \\
\text { learning climate }\end{array}$ & $\begin{array}{l}\text { Promoting and participating in } \\
\text { teacher-learning development }\end{array}$ \\
& Ensuring an orderly supportive \\
& environment \\
\hline
\end{tabular}

Instructional leadership is not just confined in formal positions held by principals, but it refers to the idea of leadership for teaching and learning (Hallinger, 2011; Robinson, 2007). Bush (2007, p. 401) specifically defines this as an influential factor that "focuses on teaching and learning and on the behaviour of teachers in working with students." Since instructional leadership covers a broad horizon of theoretical perspectives, this study aligns and synthesises the key dimensions earlier constructed by Hallinger \& Murphy (1985) with the model by Robinson (2007) as illustrated in Table 1.

Despite the progress in studies related to instructional leadership in the Asia-Pacific region (Hallinger, Wang \& Chen, 2013; Robinson, 2010), studies in Malaysia have been confined in the investigation of the responsibilities of the principals in line with Malaysia's Education Blueprint (Harris et al, 2017; Abdullah \& Kassim, 2011). Hallinger (2011) reported that from the 1980's until 2010, there were 6 studies in Malaysia that investigated the roles of principals as instructional leaders using the Principal Instructional Management Rating Scale (PIMRS). Other than the function of 
principals, some studies highlight the challenges faced by principals to build capacity and create a sustainable learning environment for a top performing school (Sharma, 2011; Suraya \& Yunus, 2012; Jones et al., 2015).

Although the meta-analysis of these instructional leadership models is heavily concentrated in government schools in Malaysia (Hallinger, 2011; Tajasom \& Ariffin Ahmad, 2011), scrutinising the practice of these models in international schools in Malaysia will help extend the universality of these instructional leadership models. Hence, the succeeding sections of this article will further look into these leadership ideals in the context of international schools in Malaysia.

\section{METHODOLOGY}

In the process of exploring the instructional leadership practices of leaders in international schools in Malaysia, this study followed the standards of a qualitative approach. An interpretive qualitative approach brings out an in-depth exploration of the phenomenon in this reality (Cohen et al., 2011; Creswell, 2012). Hence, this case study utilised multiple methods of data collection (i.e. semi-structured interviews, observation field notes, and document analysis) designed to capture the essence of instructional leadership practices in international schools in Malaysia.

This case study involved three international schools in Kuala Lumpur, which were chosen purposively based on the following criteria: year of establishment; population of students and teachers; and, curriculum. According to Bryman (2012), criteria are set in purposive sampling as a strategic way to select schools with key characteristics relevant to answering the research questions. Kuala Lumpur, being 
the capital city, has the highest concentration of international schools in Malaysia (PEMANDU, 2013); hence, there is a high potential for this city to be a rich source of information for this study. Likewise, the schools involved were considered to be well-established schools in terms of the number of enrolees and the long years of service, which could be attributed to past or existing leadership practices. The population and curriculum were set to justify the schools according to how international schools were defined earlier in this paper. Due to confidentiality and research ethics, the schools' names were replaced by School A, School B, and School C as shown in Table 2 below:

Table 2: Profile of selected international schools

\begin{tabular}{cccc}
\hline International School & Curriculum & $\begin{array}{c}\text { Student } \\
\text { Population }\end{array}$ & $\begin{array}{c}\text { Year of } \\
\text { Establishment }\end{array}$ \\
\hline School A & $\begin{array}{c}\text { International } \\
\text { Baccalaureate } \\
\text { School B }\end{array}$ & 1,010 & 1978 \\
School C & $\begin{array}{c}\text { Curriculum } \\
\text { American } \\
\text { Curriculum and } \\
\text { International } \\
\text { Baccalaureate (IB) }\end{array}$ & 450 & 1988 \\
& & 1965 \\
\hline
\end{tabular}

Furthermore, using purposive and snowball sampling, six school leaders from the three schools agreed to take part in semi-structured interviews focusing on instructional leadership practices in their respective schools. The different positions and affiliations of the school leaders ensure diversified contexts for interpretation. Due to confidentiality and research ethics, 'School Leader' or 'SL' replaced the names of the respondents. 
Through the semi-structured interviews, the school leaders responded to openended questions designed to explore instructional leadership practices in international schools. These questions were framed after the key dimensions from the synthesised models of Hallinger \& Murphy (1985) and Robinson (2007). The instruments were pilot tested and validated to ensure clarity and appropriateness, as well as to avoid ambiguous and misleading queries. In pilot testing, a school leader from an international school in Klang Valley, Malaysia agreed to take part in a mock interview and gave feedback on the quality of questions as well as the flow of the interview. A language expert went through the interview protocol to ensure clarity of wording and the structure of the questions.

Following protocol, permission to conduct research in these schools was first acquired through gatekeepers and direct correspondence with school leaders. Since these international schools are privately run institutions, requesting for permission to conduct research followed the requirements of the school's administration. The audio-recorded interviews with the school leaders ran between 40 to 60 minutes on average. After which, the responses from the interviews were fully transcribed and inductively coded using Atlas.ti and thematically analysed. Member checking helped ensure that coding was done appropriately and consistently.

Moreover, triangulation strengthens credibility of the findings of this study as it establishes the trustworthiness of the collected date through multiple instruments (Ary et al., 2010). All three schools allowed observation of the school's surroundings and provided documents (i.e. newsletters, school magazines, websites, student's handbook, and annual report) supporting the implementation of certain 
instructional leadership practices. Hence, the findings reported in this study are the ones triangulated with the observation field notes and relevant documents-all of which were coded and thematically analysed using Atlas.ti in relation to the instructional leadership practices of school leaders.

From the data collected from these qualitative instruments, an extensive presentation of findings on instructional leadership practices in international schools will be explained in the succeeding sections.

\section{FINDINGS}

From their experiences in their respective positions, all international school leaders who participated in this study shared their leadership practices and perspectives in their respective schools. Despite having different responsibilities, every school leader plays a key role in the academic and co-curricular operations of the school (Bush, 2007; Keller, 2015). Table 3 provides demographic information of the school leaders who responded to the interview:

Table 3: Profile of school leaders who participated in this study

\begin{tabular}{ccccc}
\hline & School & Position & Gender & $\begin{array}{c}\text { Years in current } \\
\text { school (position) }\end{array}$ \\
\hline SL 1 & $\mathrm{A}$ & Principal & $\mathrm{M}$ & 2 \\
SL 2 & $\mathrm{A}$ & Subject Head of & $\mathrm{F}$ & 4 \\
& & Department & & 3 \\
SL 3 & $\mathrm{A}$ & Senior Team Leader & $\mathrm{M}$ & 2 \\
SL 4 & $\mathrm{B}$ & Principal & $\mathrm{F}$ & 2 \\
SL 5 & $\mathrm{C}$ & Principal & $\mathrm{M}$ & \multicolumn{2}{c}{} \\
SL 6 & $\mathrm{C}$ & Head of School & $\mathrm{F}$ & 4 \\
\hline
\end{tabular}

*SL=School Leader 
Leadership responsibility does not only rely on the principal or the head of school, but also on formal positions like subject head of department, coordinator, or level leader (Hayden \& Thompson, 2008). Every school leader interviewed was fully aware of his or her leadership responsibilities. The principal from School C noted:

"My leadership is one [that says] this is our community. Our parents come in here, my doors are open, they can come and see me." (SL 5)

Likewise, the subject head of department from School A pointed out that leadership does not only rest with her but also with the teachers in her department who also serve "as mentors for other teachers." (SL 2)

This speaks of the kind of leadership in international schools, which stretches out to informal positions taken by teachers or members of the school community. As noted by Hayden and Thompson (2008), international schools reflect a distinct leadership structure such that organisational positions in international schools are flexible and could be interpreted and altered according to the governing body of the school.

\section{Defining the school's mission and establishing goals}

The school leaders who participated in the semi-structured interviews spoke of the relevance of the school's mission and vision in the way they perform in their schools. This refers to the academic and non-academic goals shared by the school leaders to the entire community, which includes teachers, students, and parents (Hallinger, 2009; Robinson, 2007). 
More than just words posted in classrooms or on strategic walls around the schools, the school's mission and vision play a crucial role in the practices of school leaders. Since these schools also run under the accreditation of international organisations like the International Baccalaureate Organization (IBO), they have to align the school's mission and vision with that of these accrediting organisations (Hayden \& Thompson, 2008). The head of school from School C pointed out the significance of defining the school's mission as a part of her leadership practice:

"It is through our mission, vision [that] we constantly reiterate the fact that we are all the same and that we are all equal- it doesn't matter where you come from, what you look like, or how you dress." (SL 6)

In addition, the school leaders also refer to the mission and vision of the accrediting organisations in setting the directions in their school as expressed by the subject head of department:

"Not only [that] we focus on what are set by IB, knowing we run an IB school, [our] main goal is having diversity in the curriculum." (SL 2)

Communicating the school's mission and vision also sets the tone in establishing goals and expectations through the school's core values. The principal from School C mentioned:

"It's my job to ensure that everybody knows them and that we apply those core values in everything we do in school." (SL 5) 
In this environment where different ideals exist, values serve as a binding agent so that the school itself will only head towards a common direction (Lumby \& Coleman, 2007). As the head of school from School C voiced out:

"We constantly reiterate the fact that we are all the same and that we are all equal. It doesn't matter where you come from." (SL 6)

As observed in all three schools, the mission-vision statement of the school can be seen in every classroom and common halls. The mission-vision statement of the three schools carries common words like 'international' or 'global' that amplify the idea of embracing a culturally diverse environment.

\section{Managing the instructional program and coordinating the curriculum}

As earlier mentioned, international schools follow a particular curriculum prescribed by an accrediting body. International school leaders ensure that their schools follow the curriculum of the international organisation they are affiliated with. In the context of American Curriculum, the principal from School C explained:

"For example, in 7th Grade they'll be studying things about the Holocaust and in 8th Grade they're studying human trafficking and in 6th Grade they study disaster relief. So, they are looking at [an] international global perspective based on the curriculum." (SL 5)

Although IBO and IGCSE provide the framework, it is still up to the schools and the school leaders to determine the content or topics that align the demands of the 
curriculum with the needs of their learners. Since School A follows the IB system, they have the flexibility to choose the learning materials and resources as long as they are addressing the prescribed "Global Context" from IBO as described by the senior team leader from School A:

"So, when the Global Context is about Personal and Cultural Expression, it somehow must link our syllabus [and] curriculum planning." (SL 3)

Furthermore, the IBO documents gathered from School A and School C explain the use of Global Contexts (i.e. Personal and Cultural Expression) and concepts (i.e. Communication) to facilitate conceptual learning for personal and universal relevance (IBO, 2014).

The responses from the school leaders reflect their understanding of their adopted curriculum through planning and implementation. From the National Curriculum for England and the IGCSE framework, the principal from School B elaborated:

"We call ourselves International schools, although we have a UK curriculum. We have the best practices coming from every part of the world to prepare our students." (SL 4)

According to the official website of the National Curriculum for England, although there is an emphasis on the core subjects like English, Maths, and Sciences, the curriculum is designed in stages to address students' development as lifelong learners. Likewise, Cambridge's IGCSE curriculum offers more than 70 subjects 
developed for international schools students to broaden their perspectives by making connections across all these subjects (Cambridge IGCSE, 2017).

Furthermore, international school leaders are involved in continuously improving their instructional program as a part of the accreditation and evaluation from the international governing bodies the schools are associated with. The senior team leader (SL 3) from School B mentioned the regular evaluation of their school to satisfy the demands of IBO. For an international school to be accredited as an IB school, IBO's website clearly states:

"Evaluation takes place at least once every five years. As part of the process, the school engages in a self-study that is a key element in the school's continual improvement." (IBO, n.d.)

The principal from School B pointed out that teachers' perspectives play a role in ensuring the continuous development of their academic program:

"They know what's best in their academic programmes. I have a Singaporean head of department, who brings in the Singaporean perspective in Mathematics teaching." (SL 4)

In all three schools, the classrooms are decorated showcasing different perspectives from various cultures. It has been noted during the observation that learning materials from and about different parts of the world could be seen on the walls of 
the classroom. Noticeably, posters and students' works were displayed in multiple languages and contexts.

Promoting a positive school learning climate and ensuring an orderly supportive environment

School leaders shared various people-oriented practices to promote a positive school learning climate emphasising on the school's core values. International schools are distinct from other academic institutions due to its diverse school population made up of students and staff from different parts of the world (Hill, 2015; Sylvester, 2002). The principal from School C noted:

"That feeling of creating a community among our school is the single most important thing that we do. School culture out trumps everything else about education. Test scores, strategies come second to school culture." (SL 5)

Although the schools have their core values and mission-vision statements strategically posted throughout the school as observed in the schools during the course of this study, the actions of the leaders reflecting these abstract notions matter in dealing with teachers and in establishing a culture of positivity (Leithwood \& Sun, 2012). The subject head of department from School A further elaborated:

"The appreciation that I have for each teacher is what I think makes our department even stronger. I hope what the teachers learned from the department could be transferred to the student's life--the sense of acceptance and accountability." (SL 2) 
Since leaders talk about certain values and transmit them to their teachers, this sets a domino effect on the school's population particularly the students. The senior team leader (SL 3) from School A seconded the observation on acceptance and accountability:

"Even during break time or activities, you see [the students] mix around. They don't really see the point of this boy or girl coming from a different country. They don't go beyond thinking that he is from a different country."

Festive celebrations and various school activities were also mentioned to have an effect on the school's overall climate. Even though Malaysia is an Islamic country, it is still home to Chinese, Indians, and foreigners who are free to practice their own beliefs and traditions (Noor \& Leong, 2013). The Malaysian government has holidays in place to celebrate cultural festivities like 'Hari Raya' for Muslims, Chinese New Year, 'Deepavali' for Hindus, and Christmas for Christians. Similarly, since international schools function within the Malaysian society, they have to recognise these holidays. Moreover, by celebrating these holidays, schools acknowledge the different members of their stakeholders by celebrating their festivities and having school activities in recognition of other nationalities as explained by the head of school from School C:

"We have special assemblies for the major holidays. We dress in costumes celebrating the holidays. We have an all-school International Festival each 
year that celebrates our diversity complete with costumes, food, parades, and talent from various countries." (SL 6)

Although differences might be perceived as chaotic in nature, it is through the initiative of the school leaders to highlight the importance of school culture through the mission, core values, and celebrations that sets a common tone. The idea of commonness promoted through a positive school culture dissolves the differences in this environment, which then leads to the idea of collaboration (Lumby \& Coleman, 2007).

When school leaders invite members of the community to work together despite their differences, they forge an environment of learning through collaboration. The idea of collaborative and participative leadership stems out from the positive school climate established by the school leaders through welcoming vision and values of acceptance (Le Fevre \& Robinson, 2014). The principal from School B noted:

"We're not just collegial, but it's also collaborative. You can't collaborate unless you trust the people that you work with." (SL 4)

In this case, the concentration of responsibility and accountability does not just rely with the school leaders but also with the other leaders and teachers in developing people whether they are in a formal or informal position (Harris, 2011). The head of department from School C pointed out: 
"To be mentors for other teachers, to be able to head a level through, I trust that they can do it. I trust these leadership qualities so we work as a team."

From the school leaders and teachers, the sense of collaboration is passed on to students. The same values of trust and respect between leaders and teachers are also applied on students whether they are involved in a classroom exercise or a school activity. In the classroom setting, the senior team leader observed:

"There is no way that we segregate [the students] according to the country they came from. Everyone is mixed around and collaborates." (SL 3)

The way school leaders perform in this culturally diverse environment naturally opens up possibilities in developing a positive learning climate. One of the school leaders (SL 5) discussed his role in this environment:

"I have to create the environment of trust because that creates a school climate where people want to be. People want to work in a place where they feel that they can be independent, trusted, and they're respected." (SL 5)

Generally, the findings from the qualitative instruments reveal essential leadership practices of international school leaders in their respective schools. Despite coming from different schools and backgrounds, the responses from the school leaders and teachers provided images of how school leaders perform in an international school based on key dimensions of contemporary instructional leadership models. 
The level of awareness shown by the different school leaders regardless of their position, as well as the responses from the teachers, manifest that such practices do not solely rely on the school principal. Thus, the qualitative data suggest indications of instructional leadership attributes in the practices of the international school leaders involved in this study.

\section{DISCUSSION}

As an embodiment of $21^{\text {st }}$ century education, international schools present how instructional leadership models could be utilised in a multicultural environment. In scrutinising how international school leaders perform in their schools, two contemporary models in instructional leadership were used as a contextual framework in limiting the broad scope of leadership in schools. Likewise, conducting the study in Malaysia, a predominantly Islamic yet multiracial country, brings forth a different socio-geographical context contributing to the enrichment of this field of study.

Evidently, the responses reflect that the practices of international school leaders perfectly fit the parameters of instructional leadership. The six school leaders talked about how they define the school's mission, manage the curriculum and develop a positive learning climate, which are the three key dimensions of instructional leadership according to Hallinger and Murphy (1985). However, the data inclined more towards how the school leaders and their actions lead to promoting a positive school climate and ensuring an orderly supportive environment by emphasizing the school's core values and by celebrating diversity in this multicultural environment. 
Despite clear findings linked to instructional leadership, this study is still limited in understanding other key dimensions in instructional leadership proposed by Robinson (2007). The overlapping dimensions between the two models do not provide sufficient indicators as to how international school leaders conduct strategic resourcing as well as promoting and participating in teacher-learning development.

Although the school leaders talked about these dimensions, the interviews did not produce any response on staff resourcing and developing cultural understanding among teachers. Similarly, the school leaders did not mention anything about the other minor dimensions specified by Hallinger \& Murphy (1985) on how they protect instructional time and provide incentives for teachers. Hence, this study calls for furthermore exploratory studies on these specific dimensions of instructional leadership in international schools.

\section{CONCLUSION}

Due to the limited extent of this research, a more extensive study is warranted that could cover more international schools willing to participate and share their practices for the development of existing literature. This study only presented common practices of six school leaders from three international schools in Malaysia from the context of instructional leadership. Furthermore, correlational studies on how leadership practices affect students' performance and teachers' satisfaction could be possible areas for future research.

As for leaders in international schools, it is recommended to strengthen existing practices in line with instructional leadership in order to reap its rewards. Alongside 
improving instructional leadership practices, empirical evidence from metaanalytical studies shows positive impact of this leadership construct on student outcomes in government schools (Hallinger et al., 2013; Robinson, 2010). Therefore, further investigation on how international school leaders build capacity and develop new approaches may fill the gap of this study. Other than that, other instructional leadership models could also be explored in other international schools as to how school leaders perform in this multicultural environment.

This study has only scratched the surface of international school leadership in Malaysia. In presenting instructional leadership practices in international schools, the next big question is how these could be applied in the continuous improvement of academic organisations and the global society in general. 


\section{REFERENCES}

Abdullah, J. B., \& Kassim, J. M. (2011). Instructional leadership and attitude towards organizational change among secondary schools principal in Pahang, Malaysia. Procedia-Social and Behavioral Sciences, 15, 3304-3309.

Ary, D., Jacobs, L. C., Razavieh, A., \& Sorensen, C. (2010). Introduction to research in education ( $8^{\text {th }}$ ed). Belmont, CA: Wadsworth.

Bailey, L. (2015). The experiences of host country nationals in international schools: A case-study from Malaysia. Journal of Research in International Education, 14(2), 85-97.

Bates, R. (2012). Is global citizenship possible, and can international schools provide it?. Journal of Research in International Education, 11(3), 262-274.

Bryman, A. (2012). Social Research Methods (4th ed.). Oxford: Oxford University Press.

Bush, T. (2007). Educational leadership and management: theory, policy, and practice. South African Journal of Education, 27(3), 391-406.

Cambridge IGCSE (2017). Retrieved April 01, 2017, from http://www.cie.org.uk/programmes-and-qualifications/cambridgesecondary-2/cambridge-igcse/curriculum/

Cambridge, J., \& Thompson, J. (2004). Internationalism and globalization as contexts for international education. Compare: A Journal of Comparative and International Education, 34(2), 161-175.

Cohen, L., Manion, L., \& Morrison, K. (2011). Research methods in education (7th ed.). London: Routledge. 
Creswell, J. W. (2012). Educational research: Planning, conducting, and evaluating quantitative and qualitative research ( $4^{\text {th }}$ ed.) Boston: Boston: Pearson

Fink, D. (2005). Leadership for mortals: Developing and sustaining leaders of learning. London: Paul Chapman Publishing.

Hallinger, P. (2009). Leadership for 21st century schools: From instructional leadership to leadership for learning. Hong Kong: The Hong Kong Institute of Education.

Hallinger, P. (2011). A review of three decades of doctoral studies using the principal instructional management rating scale: A lens on methodological progress in educational leadership. Educational Administration Quarterly, 47(2), 271306.

Hallinger, P., \& Murphy, J. (1985). Assessing the instructional management behavior of principals. The Elementary School Journal, 86(2), 217-247.

Hallinger, P., Wang, W.-C., \& Chen, C.-W. (2013). Assessing the Measurement Properties of the Principal Instructional Management Rating Scale A MetaAnalysis of Reliability Studies. Educational Administration Quarterly, 49(2), 272-309.

Harris, A. (2011). Distributed leadership: Implications for the role of the principal. Journal of Management Development, 31(1), 7-17.

Harris, A., Jones, M., Cheah, K. S. L., Devadason, E., \& Adams, D. (2017). Exploring Principals' Instructional Leadership Practices in Malaysia: Insights and Implications. Journal of Educational Administration, 55(2), 207-221. 
Hayden, M., \& Thompson, J. (2008). International schools: Growth and influence. Paris, France: UNESCO

Hill, I. (2015). What is an international school?. The International Schools Journal, $35(1), 9-21$.

IBO. (n.d.). Moving forward as an IB School. Retrieved April 01, 2017, from http://www.ibo.org/become-an-ib-school/timeline-and-stages/movingforward-as-an-ib-world-school/

International Baccalaureate Organization (IBO). (2014). MYP: From principles into practice. UK: IBO.

Jones, M., Adams, D., Tan, M.H.J., Muniandy, V., Perera, C.J. and Harris, A. (2015), “Contemporary challenges and changes: principals' leadership practices in Malaysia", Asia Pacific Journal of Education, 35 (3), 353-365.

Keung, E., \& Rockinson-Szapkiw, A. J. (2013). The relationship between transformational leadership and cultural intelligence: A study of international school leaders. Journal of Educational Administration, 51(6), 836-854.

Keller, D. (2015). Leadership of international schools: Understanding and managing dualities. Educational Management Administration \& Leadership, 43(6), 900917.

Le Fevre, D. M., \& Robinson, V. M. (2014). The interpersonal challenges of instructional leadership principals' effectiveness in conversations about performance issues. Educational Administration Quarterly, 51(1), 58-95. 
Lee, M., Hallinger, P., \& Walker, A. (2012). Leadership challenges in international schools in the Asia Pacific region: evidence from programme implementation of the International Baccalaureate. International Journal of Leadership in Education, 15(3), 289-310.

Leithwood, K., \& Sun, J. (2012). The nature and effects of transformational school leadership: A meta-analytic review of unpublished research. Educational Administration Quarterly, 48(3), 387-423.

Lumby, J., \& Coleman, M. (2007). Leadership and diversity: Challenging theory and practice in education. London: Sage Publications Ltd.

Mancuso, S. V., Roberts, L., \& White, G. P. (2010). Teacher retention in international schools: The key role of school leadership. Journal of Research in International Education, 9(3), 306-323.

Ministry of Education. (2012). Malaysia Education Blueprint 2013-2025. Retrieved May 28, 2016, from http://www.moe.gov.my/userfiles/file/PPP/PreliminaryBlueprint-Eng.pdf

Musa, K., \& Noor, M. A. M. (2017). School Principal Holistic Leadership: A Study in High Performance Schools in the Central Zone, Malaysia. International Journal of Academic Research in Business and Social Sciences, 7(2), 678-685.

Nasa, A. \& Pilay, S. (2017, April 23). International Schools: Why their numbers are growing. New Straits Times. Retrieved from https://www.nst.com.my/ 
Noor, N. M., \& Leong, C. H. (2013). Multiculturalism in Malaysia and Singapore: Contesting models. International Journal of Intercultural Relations, 37(6), 714-726.

PEMANDU. (2013). EPP 3: Scaling Up of International Schools. Retrieved from http://etp.pemandu.gov.my/Education-@-Education_-_EPP_3;_Scaling_Up_of_International_Schools.aspx

Robinson, V. (2007). "The impact of leadership on student outcomes: Making sense of the evidence." 2007-The Leadership Challenge-Improving learning in schools, 12-16.

Robinson, V. M. (2010). From instructional leadership to leadership capabilities: Empirical findings and methodological challenges. Leadership and Policy in Schools, 9(1), 1-26.

Sharma, S. (2011). Attributes of school principals-leadership qualities \& capacities. In International Congress for School Effectiveness and Improvement. Limassol, Cyprus.

Sharma, S. (2012). Instructional leadership model through Asian principals' perspectives. In International Conference on Education and Management Innovation IPEDR (pp. 17-21). Singapore: IACSIT Press.

Suraya, W. H., \& Yunus, J. N. (2012). Principal leadership styles in high-academic performance of selected secondary schools in Kelantan Darulnaim. International Journal of Independent Research and Studies, 1 (2), 57-67.

Sylvester, R. (2002). Mapping International Education A Historical Survey 1893-1944. Journal of Research in International Education, 1(1), 90-125. 
Tajasom, A., \& Ariffin Ahmad, Z. (2011). Principals' leadership style and school climate: teachers' perspectives from Malaysia. International Journal of Leadership in Public Services, 7(4), 314-333.

Tamatea, L. (2008). A practical and reflexive liberal-humanist approach to international mindedness in international schools: Case studies from Malaysia and Brunei. Journal of Research in International Education, 7(1), $55-76$. 